\title{
DISLODGEABLE RESIDUES OF METHAMIDOPHOS IN STAKED TOMATOES
}

\author{
Arlinda Evaristo'; Gilberto Casadei de Baptista ${ }^{2 *}$ \\ ${ }^{1}$ Syngenta Proteção de Cultivos Ltda. Av. Nações Unidas, 18.001- CEP: 04795-900; São Paulo, SP. \\ ${ }^{2}$ Depto de Entomologia, Fitopatologia e Zoologia Agrícola - USP/ESALQ. C.P. 9 \\ CEP: 13418-900 - Piracicaba, SP \\ ${ }^{*}$ Corresponding author <gcbaptis@esalq.usp.br>
}

\begin{abstract}
The measurement of dislodgeable pesticide residues is a way of estimating occupational exposure of farmers in their working environment. This study evaluates dislodgeable methamidophos residues on leaves, fruits and soil in staked tomatoes (Lycopersicon esculentum Mill), with the objective of estimating potential exposure. The experiment consisted of four treatments: application of methamidophos in a single rate of 0.6 $\mathrm{g}$ a.i. $\mathrm{L}^{-1}$ water; application of a double rate of $1.2 \mathrm{~g}$ a.i. $\mathrm{L}^{-1}$ water; four applications of a single rate; and control. The first spraying in the four-application treatment was made at the beginning of fruit maturation. The later applications followed a 6-day schedule. Spraying of the treatments with one application was simultaneous to the last spraying of the four-application treatment. Leaf, fruit and soil samples were taken one day before applications, and 0, 1, 2, 3, 5, 7 and 14 days after them. Dislodgeable methamidophos residues were extracted by Sur-ten aqueous solution; extracts were partitioned in a methanol-ethyl acetate mixture, and the residues were quantified by gas chromatography on a flame photometry detector. Foliar residues in the four-application treatment at the single rate and one application at the double rate had similar degradations, with half-lives of 0.7 and 0.9 day, respectively. The behavior of soil dislodgeable residues in the treatments at a single rate (one and four applications) was similar, with half-lifes of 2.9 and 2.7 days, respectively. Residues on soil were more persistent than residues on the leaves. Residues on fruits were detected only for 0 and 1-day old samples. Results show that degradation on tomatoes is relatively fast.
\end{abstract}

Key words: Lycopersicon esculentum, pesticide residue, occupational exposure, risk

\section{RESÍDUOS DESLOCÁVEIS DE METAMIDOFÓS EM CULTURA ESTAQUEADA DE TOMATE}

\begin{abstract}
RESUMO: Resíduos deslocáveis de pesticidas são uma das formas de se estimar a exposição ocupacional do trabalhador rural no seu ambiente de trabalho. Este estudo avalia resíduos deslocáveis de metamidofós em folhas, frutos e solo em cultura estaqueada de tomate (Lycopersicon esculentum Mill), com o objetivo de conhecer o potencial dessa exposição. O experimento constou de quatro tratamentos: uma aplicação de metamidofós na dose simples de $0,6 \mathrm{~g} \mathrm{~L}^{-1}$ de água de i.a.; uma aplicação na dose dobrada de $1,2 \mathrm{~g} \mathrm{~L}^{-1}$ de água de i.a.; quatro aplicações na dose simples e testemunha. As amostras foram colhidas decorridos $-1,0$, $1,2,3,5,7$ e 14 dias. Os resíduos deslocáveis de metamidofós foram extraídos com solução aquosa de Surten e quantificados por cromatografia de gás. Nas folhas, eles tiveram degradação semelhante nos tratamentos com quatro e com uma aplicação na dose dobrada (1/2 vida de 0,7 e 0,9 dia). No solo, em ambas as doses simples ela foi também semelhante (1/2 vida de 2,9 e 2,7 dias). Os resíduos no solo foram mais persistentes do que nas folhas. Nos frutos, eles foram detectados apenas aos 0 e 1 dia, o que sugere que a degradação neles é relativamente muito rápida.

Palavras-chave: Lycopersicon esculentum, resíduos de pesticida, exposição ocupacional, risco
\end{abstract}

\section{INTRODUCTION}

About two decades ago some countries intensified studies to guarantee safe conditions against the exposure to unhealthy residues for those who work with pesticide applications. The potential danger of organophosphate residues for farmers is a classic problem in occupational health studies (Popendorf \& Leffingwell, 1982).

Exposure to pesticides, when farmers reenter treated areas, is especially important in crops that demand frequent manipulation, for harvest and other management activities. This is particularly the case of tomatoes. This crop contributes significantly to Brazilian economy, occupying, in 1998, approximately 60,000 ha, with an estimated production of 2.7 million tons. The state of São Paulo is the largest producer, with aproximately 640,000 tons (FNP Consultoria e Comércio, 1999).

Because of the relevance of pesticides, and the worker health issue, it is important to monitor the levels of pesticide residues, as a potential risk for those who are occupationally exposed. There are different ways to estimate exposure to pesticides. Nigg \& Stamper (1989) suggest environmental and biological monitoring. The first involves measurements in the working environment through passive dosimetry, quantifying the pesticides that 
become in contact with workers, using sampling devices placed on the skin and/or clothes. The biological monitoring comprises the measurement of the original compositions and their metabolites, through bioindicators. Generally these include determinations of cholinesterase levels in blood, and residues in other biological fluids, such as urine and sweat.

Another way of estimating exposure in the agricultural work environment is through the evaluation of dislodgeable residues, which consist of measuring them on the surface of leaves, fruits and on the soil of crops treated with a given pesticide. Dislodgeable residue is that portion of the pesticide on treated crops that is promptly removed and thus can be used as an indicator of the occupational risk to farmers. It is generally determined as the residue that is removed when leaf disks are shaken for a short time in water or in a soap solution (Holland, 1996). This method is an important tool for risk assessment. These data provide elements for actions aiming to reduce the risk, considering the involved cost/benefit.

The foliage of a treated crop is the primary source of toxic residues for field workers. The knowledge on the identity, level and behavior of dislodgeable foliar residues is the first step towards the protection of workers (Iwata et al. 1977).

In countries where risk assessment was made, various models were suggested, and a large quantity of data was generated. These data allowed the development of more complete models. In Brazil there is a lack of data on pesticide parameters that could be used as a basis for mathematical modeling. The identification and quantification of exposure problems is very important to support models that may be used in future for better representing real field situations.

The objective of this work was to study the occurrence and behavior of dislodgeable residues of the insecticide methamidophos on leaves, fruits and soil of a staked tomato crop.

\section{MATERIAL AND METHODS}

The experiment was carried out in a staked tomato crop, in Capivari (latitude $22^{\circ} 54^{\prime} 20^{\prime \prime} \mathrm{S}$, longitude $47^{\circ} 03^{\prime} 39^{\prime \prime}$ W), located in the State of São Paulo, Brazil. The experimental design consisted of random ized blocks with four treatments and four replications. Each plot occupied an area of $690 \mathrm{~m}^{2}(30 \mathrm{~m} \times 23 \mathrm{~m})$ with four double rows, separated by two other double row borders. The total area used in the experiment was $11,040 \mathrm{~m}^{2}$.

The applied product was a soluble concentrated formulation of $60 \%$ methamidophos $\left(600 \mathrm{~g} \mathrm{~L}^{-1}\right)$. This insecticide is an organophosphate, with the chemical name, O,S dimethyl phosphoramidothioate. Some toxicological data are: acute oral $\mathrm{LD}_{50}=20 \mathrm{mg} \mathrm{kg}^{-1}$ and acute dermal $L D_{50}=130 \mathrm{mg} \mathrm{kg}^{-1}$ rat (Tomlin, 1995). It is one of the most frequently used pesticides for tomatoes, especially for the control of aphids, leaf beetles, and small and large fruit borers. Treatments were: A. single application at a rate of $0.6 \mathrm{~g}$ a.i. $\mathrm{L}^{-1}$ of water; $\mathrm{B}$. single application at a double rate of $1.2 \mathrm{~g}$ a.i. $\mathrm{L}^{-1}$ of water; $\mathrm{C}$. four applications of a single rate of $0.6 \mathrm{~g}$ a.i. $\mathrm{L}^{-1}$ of water, at intervals of 6 days; D. control (no application).

The insecticide applications were made with a tractor-powered sprayer, equipped with a 2,000-liter tank, and hoses capped with HV-3R full cone tips. The spray mix volume was approximately $660 \mathrm{~L} \mathrm{ha}^{-1}$, for all treatments. The first application was made at the beginning of the fruiting period. At this stage developing and mature fruit were present. The second, third and fourth applications were made every 6 days thereafter (treatment $C$ ); and by the last of these the single application treatments were sprayed (A and $B)$.

Sampling was initiated the day before fourth application. The first sampling had the objective to determine dislodgeable residues in parcels that had then received three applications of pesticide, and possible contaminations from other plots. The other samples were taken $0,1,2,3,5,7$ and 14 days after the last application, and leaves, fruits and soil were collected for dislodgeable residue determination. A total of 384 field samples were collected, divided in four treatments, four repetitions, three substrates and eight harvest periods.

Each leaf sample consisted of 40 disks, $2.2 \mathrm{~cm}$ in diameter, collected in a double line on both sides, and from the upper middle and bottom parts of the plant. A mechanical punch with an attached collecting bin was used to harvest the leaf disks. These samples were processed the same day, following the suggestion of Iwata et al. (1977) and Gunther et al. (1973). Ten fruits were collected at random, along the double line of plants, from both rows. The tomatoes were held by the stem (to avoid hand contact with surface residues), placed in 5 $\mathrm{kg}$ capacity plastic bags, and taken in this way to the laboratory. They were also processed the same day they were collected.

The method of Spencer et al. (1977), adapted to local conditions, was used for soil sampling. These samples were also collected on both sides of the double planting line, in the foliage runoff area, where field workers normally stand for cultivation and harvest. A 20 $x 20 \mathrm{~cm}$ sampling device was used to remove the surface soil (approximately $1 \mathrm{~cm}$ depth). These samples were placed into $1 \mathrm{~kg}$ capacity plastic bags and taken to the laboratory. The soil was homogenized, and $25 \mathrm{~g}$ were removed. These sub-samples were wrapped in aluminum foil, frozen $\left(-20^{\circ} \mathrm{C}\right)$ until they were analyzed, within 15 days.

The method for the removal of dislodgeable residues was adapted from Iwata et al. (1977), using an aqueous Sur-ten solution (sodium dioctilsulfoccinate$70 \%$ ), as extracting solvent, at a dilution of $1: 25,000$, as suggested by Nigg et al. (1979). The residues were extracted from the Sur-ten solution by the adapted 
method of Holt \& Pease (1976). These extracts were partitioned in a mixture of $15 \%$ methanol in ethyl acetate. After the samples were concentrated, a quantitative determination was made by gas chromatography, with a flame photometric detector, containing a specific filter for phosphorous.

The leaf samples were placed in erlenmeyer flasks and $45 \mathrm{~mL}$ of diluted Sur-ten solution was added. These were then agitated at 150 cycles $\mathrm{min}^{-1}$, during 20 minutes. This procedure was repeated two more times. Aliquots of $30 \mathrm{~mL}$ were taken, and transferred to a separatory funnel, after addition of $30 \mathrm{~mL}$ of hexane and $2 \mathrm{~g}$ of $\mathrm{NaCl}$. The funnels were vigorously agitated for 1 minute and then kept still to allow the separation of the phases. The lower aqueous layer was transfered to an erlenmeyer flask, and the organic upper layer discarded. The aqueous phase was returned to the same separatory funnel, to which $30 \mathrm{~mL}$ of a mixture of $15 \%$ methanol in ethyl acetate were added. The funnel was vigorously shaken, and then held still for separation of the phases. The aqueous phase was collected into an erlenmeyer and the upper organic phase filtered through a funnel containing $20 \mathrm{~g}$ of $\mathrm{Na}_{2} \mathrm{SO}_{4}$, placed at the top of a round balloon flask with a flat bottom. This procedure was repeated twice more, and finally, the funnel containing $\mathrm{Na}_{2} \mathrm{SO}_{4}$, was washed in $10 \mathrm{~mL}$ of the solvent mixture. Four drops of ethylene glycol were added to the extract and this was then concentrated in a rotary evaporator, under vacuum in a warm water bath at $60-65^{\circ} \mathrm{C}$, until approximately $1-2 \mathrm{~mL}$. The remaining solvent was removed by vacuum and the extract taken in $10 \mathrm{~mL}$ of acetone, and transferred to a graduated centrifuge tube. Subsequently, the extract was concentrated in a water bath, with air previously dried in a gas washing bottle containing silica gel, until exactly $1 \mathrm{~mL}$ remained. The extracts were transferred to small glass flasks, to which $0.2 \mathrm{~g}$ of $\mathrm{Na}_{2} \mathrm{SO}_{4}$ was added. These were maintained at $20^{\circ} \mathrm{C}$ until quantitative determination. Determination was made by injection into a gas chromatograph, equipped with a flame photometric detector, containing a specific $526 \mathrm{~nm}$ filter for phosphorous, and a glass 1/8" diameter, 1.2 meter long chromatographic column, packed with Carbowax $20 \mathrm{M} /$ Chromosorb W, AW/DMCS. The operating temperatures were: column $170^{\circ} \mathrm{C}$, injector $230^{\circ} \mathrm{C}$ and detector $230^{\circ} \mathrm{C}$. The gas flow was: carrier $\mathrm{N}_{2}$ : $35 \mathrm{~mL} \mathrm{~min}{ }^{-1}$, air: $150 \mathrm{~mL} \mathrm{~min}{ }^{-1}$ and $\mathrm{H}_{2}: 75 \mathrm{~mL} \mathrm{~min}^{-1}$.

The method for the analysis of residues on the fruit was similar to that for leaves, with the following differences: in the case of fruit analyses, the residues were extracted in a reciprocating vertical shaker, during 15 minutes, at 35 cycles $\min ^{-1}$, and extract partitioning of Sur-ten solution in hexane was not made.

For the determination of the limits of quantitation and the percentage of methamidophos residues recovered from leaves, fruits and soil by the used methodology, samples were spiked with various concentrations of insecticide; that is, on leaves: 0.01- 0.1 $\mu \mathrm{g} \mathrm{cm}^{-2}$, on fruit: $0.02-0.1 \mu \mathrm{g} \mathrm{cm}^{-2}$ and on soil: $0.1-1$ $\mathrm{mg} \mathrm{kg} \mathrm{kg}^{-1}$, and processed in the same way as the experimental field samples. Based on these data, the lower limits for quantification and the percentage recovery were, respectively, leaves: $0.02 \mu \mathrm{g} \mathrm{cm}^{-2}$ and $72-76 \%$; fruit: $0.05 \mu \mathrm{g} \mathrm{cm}^{-2}$ and $106-117 \%$; soil: $0.1 \mathrm{mg} \mathrm{kg}^{-1}$ and $93-$ $112 \%$.

The dislodgeable residue values expressed in $\mu \mathrm{g}$ $\mathrm{cm}^{-2}$ for leaves and in $\mathrm{mg} \mathrm{kg}^{-1}$ for soil were adjusted statistically by non-linear regression, according to the mathematical model proposed by Giles \& Blewett (1991), as follows: $Q t=Q o$. $\exp (-t / k)$, where: $Q t=$ quantity of dislodgeable residue at time $\mathrm{t}$; $\mathrm{Qo}=$ initial quantity of dislodgeable residue at time 0 (to); $\mathrm{t}=$ time (days); $\mathrm{k}=$ time constant. This mathematical model was not applied to fruits because insufficient numerical data were available. In this case residues were detected only at day 0 and day 1 after the application.

\section{RESULTS AND DISCUSSION}

\section{Dislodgeable residues of methamidophos in leaves and soil}

The results found in the control were all lower than the limits of quantitation of the analytical method (< $0.02 \mu \mathrm{g} \mathrm{cm}^{-2}$, for leaves and $<0.1 \mathrm{mg} \mathrm{kg}^{-1}$ for soil) (Table 1).

The parameters $Q_{0}$ and $K$, estimated by the mathematical model, represent the degradation curve for each treatment. The $\mathrm{R}^{2}$ values for the adjusted equations are presented in Table 2 for leaves and soil.

The dislodgeable methamidophos residue levels on leaves decreased rapidly after the insecticide applications (Table 1), in both, the treatment with four applications of a single rate and in the treatment with a single double rate. This decrease was evident during the first day after the application, which is suggested by the short half-lives ( 0.7 and 0.9 days, respectively) (Table 3 ). This is probably because of the relatively high vapor pressure of the insecticide caused by the high temperatures during the sampling period $\left(30-35^{\circ} \mathrm{C}\right)$. For these two treatments, it can be observed that the dislodgeable methamidophos residues on the leaves had similar rates of degradation, based on the $\mathrm{K}$ (time constant) values (Table 2 ), as estimated by their similar half-life values.

A rainfall of $168 \mathrm{~mm}$ occurred during the period between the first and fourth applications of treatment $C$. This is probably the reason for the disappearance of the residues from the leaves in this treatment, making them, in this way, similar to the single application (treatment A). In this treatment the levels of dislodgeable residues on leaves decreased more slowly, resulting in a longer halflife (2.4 days) (Table 3 ).

The weather pattern at the experimental field during sampling, indicates that the dislodgeable insecticide residues on leaves, during the 14 days after 
application, were probably removed by heat, which increases volatilization. Temperatures reached $30-35^{\circ} \mathrm{C}$ and there was no rain during this period. This agrees with Nigg \& Stamper (1984) and Stamper et al. (1987), who found the same for other pesticides.

Comparing the half-lives of the dislodgeable methamidophos residues in the soil (Table 3 ) it is apparent that the dissipation was slower. Based on the same parameters, the two treatments with a single rate, with one or four applications performed in a similar way (2.9 and 2.7 days, respectively). Also, the occurrence of rainfall during the period between the first and fourth applications, as already mentioned, could again be the driving factor for the reduction of dislodgeable residues in the soil for treatment $C$, and was the case for the leaves. This factor caused the residues to be similar to those found in treatment $A$. This effect can also be observed in the time constants $(\mathrm{K})$, that represent degradation (Table 3 ). This indicates that rainfall and the consequent high soil water content, are factors which affect the amount of residue.

There was no rainfall neither during the sampling period, nor after all the applications, and considering the relatively high temperatures during this period (30 $35^{\circ} \mathrm{C}$ ), it is apparent that heat, or the maximum temperatures, had lower importance for the removal of residues from soil. Between the determinations made on days 7 and 14, when the maximum temperatures reached $35^{\circ} \mathrm{C}$, the levels practically did not change.
The results of the double dosage treatments show that the residues in the soil dissipated faster than those with a single rate, with a half-life of 1.3 days (Table 3 ).

When comparing the levels of residues on leaves, the soil residues were found the most important sources of contamination for field workers, because they tend to persist for a longer time. Therefore, precautions should be taken, and shoes should always be worn.

The influence of weather conditions, such as rain, relative humidity and temperature, indicate that regional differences can affect in the persistence of these residues, as suggested by Nigg \& Stamper (1982). Therefore, given the widespread use of methamidophos for tomatos in practically all producing regions of Brazil, other studies on dislodgeable residues of this product should be performed, under local conditions.

\section{Dislodgeable residues of methamidophos in fruit}

The results of the analyses of dislodgeable residues on fruit (Table 1 ) were not adjusted by the mathematical model, because measurable levels were only found on days 0 and 1 . These values were similar to those for leaf residues only on the day the applications were made $\left(0.19 \mu \mathrm{g} \mathrm{cm}^{-2}\right)$ for the single rate application. Measurements made one day after the application, present a great reduction $\left(0.05 \mu \mathrm{g} \mathrm{cm}^{-2}\right)$ and the residues could not be quantified (less than $0.05 \mu \mathrm{g} \mathrm{cm}^{-2}$ ) in subsequent samplings. Treatments $B$ and $C$ had low levels $(0.28$ and $0.11 \mu \mathrm{g} \mathrm{cm}^{-2}$, respectively) and after two days they were also not detected (less than $0.05 \mu \mathrm{g} \mathrm{cm}^{-2}$ ).

Table 1 - Dislodgeable residues of methamidophos on leaves, soil and tomato fruits (four replications).

\begin{tabular}{|c|c|c|c|c|}
\hline Treatment & $\begin{array}{c}\text { Day after } \\
\text { application }\end{array}$ & Leaf & Soil & Fruit \\
\hline \multirow{9}{*}{$\begin{array}{l}\left(0.6 \mathrm{~g} \mathrm{~L}^{-1} \text { of water of }\right. \\
\text { a.i.- } 1 \text { application) }\end{array}$} & & $\mu \mathrm{g} \mathrm{cm}^{-2}$ & $\mathrm{mg} \mathrm{kg}^{-1}$ & $\mu \mathrm{g} \mathrm{cm}^{-2}$ \\
\hline & -1 & $<0.02$ & $<0.1$ & $<0.05$ \\
\hline & 0 & $0.18 \pm 0.07$ & $2.10 \pm 0.92$ & $0.19 \pm 0.08$ \\
\hline & 1 & $0.12 \pm 0.03$ & $2.98 \pm 1.13$ & $0.05 \pm 0.01$ \\
\hline & 2 & $0.06 \pm 0.00$ & $1.08 \pm 0.36$ & $<0.05$ \\
\hline & 3 & $0.05 \pm 0.01$ & $1.12 \pm 0.68$ & $<0.05$ \\
\hline & 5 & $0.05 \pm 0.02$ & $0.73 \pm 0.12$ & $<0.05$ \\
\hline & 7 & $0.02 \pm 0.00$ & $0.45 \pm 0.17$ & $<0.05$ \\
\hline & 14 & $<0.02$ & $0.45 \pm 0.10$ & $<0.05$ \\
\hline \multirow{8}{*}{$\begin{array}{l}\left(1.2 \mathrm{~g} \mathrm{~L}^{-1} \text { of water of }\right. \\
\text { a.i.- } 1 \text { application) }\end{array}$} & -1 & $<0.02$ & $<0.1$ & $<0.05$ \\
\hline & 0 & $0.96 \pm 0.43$ & $8.60 \pm 4.43$ & $0.28 \pm 0.04$ \\
\hline & 1 & $0.39 \pm 0.13$ & $5.65 \pm 5.11$ & $0.06 \pm 0.02$ \\
\hline & 2 & $0.26 \pm 0.10$ & $1.49 \pm 1.08$ & $<0.05$ \\
\hline & 3 & $0.10 \pm 0.04$ & $1.17 \pm 0.53$ & $<0.05$ \\
\hline & 5 & $0.07 \pm 0.01$ & $1.33 \pm 0.75$ & $<0.05$ \\
\hline & 7 & $0.04 \pm 0.00$ & $0.44 \pm 0.23$ & $<0.05$ \\
\hline & 14 & $<0.02$ & $0.47 \pm 0.20$ & $<0.05$ \\
\hline \multirow{8}{*}{$\begin{array}{l}\left(0.6 \mathrm{~g} \mathrm{~L}^{-1} \text { of water of }\right. \\
\text { a.i.- } 4 \text { applications })\end{array}$} & -1 & $0.03+0.00$ & $<0.1$ & $<0.05$ \\
\hline & 0 & $0.39 \pm 0.09$ & $2.93 \pm 0.91$ & $0.11 \pm 0.06$ \\
\hline & 1 & $0.10 \pm 0.02$ & $3.50 \pm 0.38$ & $0.05 \pm 0.01$ \\
\hline & 2 & $0.07 \pm 0.03$ & $0.76 \pm 0.14$ & $<0.05$ \\
\hline & 3 & $0.07 \pm 0.02$ & $1.56 \pm 0.30$ & $<0.05$ \\
\hline & 5 & $0.15 \pm 0.04$ & $1.08 \pm 0.41$ & $<0.05$ \\
\hline & 7 & $0.02 \pm 0.00$ & $0.50 \pm 0.14$ & $<0.05$ \\
\hline & 14 & $<0.02$ & $0.47 \pm 0.24$ & $<0.05$ \\
\hline
\end{tabular}


Table 2 - Initial deposition values $\left(Q_{o}\right)$, time constant $(K)$ and determination coefficient $\left(R^{2}\right)$, estimated by non-linear regression of the leaf and soil samples ${ }^{1}$.

\begin{tabular}{|c|c|c|c|c|c|}
\hline \multirow{2}{*}{ Treatment } & \multirow{2}{*}{$Q_{0}$} & \multirow{2}{*}{$\mathrm{K}$} & \multirow{2}{*}{$\mathrm{R}^{2}$} & \multicolumn{2}{|c|}{ Confidence interval $_{(0.05)}$} \\
\hline & & & & $Q_{0}$ & $\mathrm{~K}$ \\
\hline \multicolumn{6}{|c|}{--- \% --- } \\
\hline \multicolumn{6}{|c|}{ Leaf sample } \\
\hline $\begin{array}{l}0.6 \mathrm{~g} \mathrm{~L}^{-1} \text { of water of } \\
\text { a.i. (1 application) }\end{array}$ & $0.1562( \pm 0.026)$ & $3.4879( \pm 1.249)$ & 91.7 & $0.0881-0.2242$ & $0.2762-6.6996$ \\
\hline $\begin{array}{l}1.2 \mathrm{~g} \mathrm{~L}^{-1} \text { of water of } \\
\text { a.i. (1 application }\end{array}$ & $0.9456( \pm 0.038)$ & $1.3197( \pm 0.109)$ & 99.3 & $0.8477-1.0435$ & $1.0375-1.6019$ \\
\hline $\begin{array}{l}0.6 \mathrm{~g} \mathrm{~L}^{-1} \text { of water of } \\
\text { a.i. (4 applications) }\end{array}$ & $0.3772( \pm 0.068)$ & $1.0675( \pm 0.421)$ & 87.6 & $0.2016-0.5528$ & $0.1663-2.1516$ \\
\hline \multicolumn{6}{|c|}{ Soil sample } \\
\hline $\begin{array}{l}0.6 \mathrm{~g} \mathrm{~L}^{-1} \text { of water of } \\
\text { a.i. (1 application) }\end{array}$ & $2.4952( \pm 0.457)$ & $4.3158( \pm 1.757)$ & 90.8 & $1.3182-3.6721$ & $0.2015-8.8331$ \\
\hline $\begin{array}{l}1.2 \mathrm{~g} \mathrm{~L}^{-1} \text { of water of } \\
\text { a.i. (1 application) }\end{array}$ & $8.7072( \pm 0.494)$ & $1.9718( \pm 0.223)$ & 98.8 & $7.4358-9.9786$ & $1.3978-2.5457$ \\
\hline $\begin{array}{l}0.6 \mathrm{~g} \mathrm{~L}^{-1} \text { of water of } \\
\text { a.i. (4 applications) }\end{array}$ & $3.1732( \pm 0.615)$ & $3.8720( \pm 1.624)$ & 89.6 & $1.5902-4.7563$ & $0.3025-8.0466$ \\
\hline
\end{tabular}

${ }^{1}$ the standard errors of the mean are given in parentheses

Table 3 - Half life values for dislodgeable methamidophos residues calculated by non-linear regression for leaf and soil samples.

\begin{tabular}{lcc}
\hline \multirow{2}{*}{ Treatment } & \multicolumn{2}{c}{ Half-life (day) } \\
\cline { 2 - 3 } & Leaves & Soil \\
\hline $0.6 \mathrm{~g} \mathrm{~L} \mathrm{~L}^{-1}$ of water of a.i. (1 application) & 2.4 & 2.9 \\
$1.2 \mathrm{~g} \mathrm{~L}^{-1}$ of water of a.i. (1 application) & 0.9 & 1.3 \\
$0.6 \mathrm{~g} \mathrm{~L} \mathrm{~L}^{-1}$ of water of a.i. (4 application) & 0.7 & 2.7 \\
\hline
\end{tabular}

The rapid dissipation on fruits can be explained by the fact that they have a very smooth and waxy surface, which favors the drip off of the spray mixture, and therefore only small quantities of the chemicals remain on the fruits.

\section{REFERENCES}

FNP CONSULTORIA E COMÉRCIO. Tomate. AGRIANUAL - 1999. São Paulo, 1999, p.489-497.

GILES, D.K.; BLEWETT, T.C. Effects of conventional and reduced-volume, charged-spray application techniques on dislodgeable foliar residue of captan on strawberries. Journal of Agricultural and Food Chemistry, v.39, p.1646-1651, 1991.

GUNTHER, F.A.; WESTLAKE, W.E.; BARKLEY, J.H. Establishing dislodgeable pesticide residues on leaf surfaces. Bulletin of Environmental Contamination and Toxicology, v.9, p.243-249, 1973.

HOLLAND, P.T. Glossary of terms relating to pesticides. Pure and Applied Chemistry, v.68, p. 1167-1193, 1996.

HOLT, R.F.; PEASE, H.L. Gas chromatographic determination of Monitor (O,Sdimethyl phosphoramidothioate) residues in crops. Journal of Agricultural and Food Chemistry, v.24, p.263-266, 1976.
IWATA, Y.; KNAAK, J.B.; SPEAR, R.C.; FOSTER, R.J. Worker reentry into pesticide-treated crops: I. Procedure for the determination of dislodgeable pesticide residues on foliage. Bulletin of Environmental Contamination and Toxicology, v.18, p.649-655, 1977.

NIGG, H.N.; ALLEN, J.C.; KING, R.W. Behavior of parathion residues in Florida Valencia orange agroecosystem. Journal of Agricultural and Food Chemistry, v.27, p.578-582, 1979.

NIGG, H.N.; STAMPER, J.H. Regional considerations in worker reentry. In PLIMMER, J.R. (Ed.) Pesticide residues and exposure. Washington: American Chemical Society, 1982. p.69-73. (ACS Symposium Series, 182)

NIGG, H.N.; STAMPER, J.H. Dislodgeable residues of chlorobenzilate in Flórida citrus: workers reentry implications. Chemosphere, v.13, p.11431156, 1984.

NIGG, H.N.; STAMPER, J.H. Biological monitoring for pesticide dose determination. Historical perspectives, current practices, and new approaches. In: WANG, R.G.M.; FRANKLIN, C.A.; HONEYCUTT, R.C.; REINERT, J.C. (Ed.) Biological monitoring for pesticide exposure: measurement, estimation, and risk reduction. Washington: American Chemical Society, 1989. p.6-27. (Symposium Series, 382).

POPENDORF, W.J.; LEFFINGWELL, J.T. Regulation OP pesticide residues for farmworker protection. Residue Reviews, v.82, p.125-201, 1982.

SPENCER, W.F.; KILGORE, W.W.; IWATA,J.; KNAAK, J.B. Worker reentry into pesticide-treated crops: II. Procedures for the determination of pesticide residues on the soil surface. Bulletin of Environmental Contamination and Toxicology, v.18, p.656-662, 1977.

STAMPER, J.H.; NIGG, H.N.; QUEEN, R.M. Dislodgeable captan residues at strawberry farms. Chemosphere, v.16, p.1257-1271, 1987.

TOMLIN, C. The pesticide manual: a world compendium. 10.ed. London The Royal Society of Chemistry, 1995. p.673-674: 462 Methamidophos.

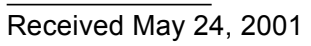

